\title{
How Mary Ellen Avery influenced my career as an investigator
}

\author{
Cynthia Frances Bearer* \\ Pediatrics, University of Maryland School of Medicine, Baltimore, MD, USA \\ ${ }^{*}$ Correspondence: cbearer@peds.umaryland.edu \\ Edited and reviewed by: \\ John Steven Torday, University of California Los Angeles, USA
}

Keywords: Mary Ellen Avery, tribute, career influences, simple observations, mentor

I arrived in Boston during the summer of 1984, having been coaxed there by F. Sessions Cole, III. The carrot was the shortening of residency to 2 years, and thus a return to the lab all the quicker. Dr. Avery was the chair of the department at that time, and so supported my bid to enter the Special Alternative Pathway. While that may sound easy, I had unintentionally made it more difficult by doing my internship as my fourth year of medical school. To the American Board of Pediatrics, on paper, I had done only a year of residency, and would not be board eligible if I left my residency program. After much negotiation, the Johns Hopkins University School of Medicine recalled my diploma, and reissued it with a graduating date of 1982 rather than 1983. And thus I started my fellowship after 2 years of official residency! And did get back to the lab a year sooner than otherwise.

The next issue to be solved was one of housing. In order to access the Harvard University housing office, I needed a note from the chair. I believe this is the only personal note I have signed by Dr. Avery, but it guaranteed me a place to live while getting to work on my clinical and research training.

More importantly, her own research work was inspirational for me in my research career. Namely, the ability to see the importance in common observations that others did not recognize. Her observation that babies who died of respiratory distress syndrome (RDS) had no bubbles in their airways, whereas babies who died of other causes had these bubbles (1). This seemingly simple observation lead to the gastric aspirate shake test (2), the identification of lack of surfactant in RDS (3), development of surfactant therapies (4), development of pharmacotherapies (prenatal steroids) for the preventions of RDS (5), etc. For my own work, I have tried to make simple observations. My first simple observation was that the then recently described non-oxidative metabolites of ethanol, fatty acid ethyl esters (FAEE), accumulate in adipose tissue, so they might accumulate in meconium. Meconium is the accumulated gastrointestinal contents during gestation which is passed soon after birth and is presumed to be metabolically inert. Thus, meconium could be a dosimeter for prenatal ethanol exposure. I developed a simple method of extracting FAEE from meconium (6), and then was able to validate that they were associated with maternal self-reported drinking during pregnancy in several different populations (7-9), and that they indicated children at risk for poor neurodevelopmental outcomes (10). I was even able to demonstrate that they accumulate in sheep meconium (11)! For these experiments, I received NIH funding, several publications, and a patent!

The next simple observation was actually made by someone else - that patients with fetal alcohol syndrome and patients with a mutation in the gene for $\mathrm{L} 1$ cell adhesion molecule (L1) had very similar neuropathologies (12). This observation led to the hypothesis that L1 is a target for ethanol developmental neurotoxicity. I was able to build on this observation that the neurite outgrowth promoted by L1 was exquisitely sensitive to ethanol, whereas that promoted by laminin or $\mathrm{N}$-cadherin was not (13). This lead to my own simple observation that, since L1 promotes neurite outgrowth via trafficking through a lipid raft compartment, and laminin and
$\mathrm{N}$-cadherin do not, then ethanol may target the L1-lipid raft interaction (14). These observations lead to the next series of simple questions, such as, if ethanol has an effect on lipid raft trafficking, do other solvents? (Answer - yes). If the lipid raft is the target for ethanol, are there unique and novel interventions for the impact of ethanol on the developing central nervous system? (Answer - yes). So, after several grants and many publications, we are poised to begin the next series of simple observations that will hopefully improve neurodevelopmental outcomes following neurotoxicant exposure, including ethanol, toluene, bilirubin, volatile anesthetics, and chlorhexidine.

One more simple observation occurred to me early in my career. The observation was that we use adult blood to transfuse into our very low birth weight (VLBW) babies. Adults are known to be exposed to lead, mercury, and other heavy metals, some at occupational levels of exposure that would be inappropriate and dangerous for children. Adults who work with lead are monitored for their blood lead level which can be as high as $45 \mathrm{mg} / \mathrm{dL}$ before being removed from the position that is causing the exposure. Yet, donated blood is not screened for potentially high levels of heavy metals. We have shown that the blood lead concentration increases following transfusions in VLBW, and that about $25 \%$ of donor blood has concerning levels of lead $(15,16)$. We are now engaged in research to determine if the cumulative dose of lead or mercury is a risk factor for poorer neurodevelopmental outcome of our most vulnerable patients.

Thank you Dr. Avery for your gift of simple observations! 


\section{REFERENCES}

1. Avery ME. Surfactant deficiency in hyaline membrane disease: the story of discovery. Am J Respir Crit Care Med (2000) 161:1074-5. doi:10.1164/ ajrccm.161.4.16142

2. Farrell PM, Avery ME. Hyaline membrane disease. Am Rev Respir Dis (1975) 111:657-88.

3. Avery ME, Mead J. Surface properties in relation to atelectasis and hyaline membrane disease. AMA J Dis Child (1959) 97:517-23.

4. Taeusch HW, Keough KM, Williams M, Slavin R, Steele E, Lee AS, et al. Characterization of bovine surfactant for infants with respiratory distress syndrome. Pediatrics (1986) 77: 572-81.

5. Rokos J, Vaeusorn O, Nachman R, Avery ME. Hyaline membrane disease in twins. Pediatrics (1968) 42:204-5.

6. Bearer CF. Detection of Teratogen Exposure. US patent no. 5,952,235 (1999).

7. Bearer CF, Jacobson JL, Jacobson SW, Barr D, Croxford J, Molteno CD, et al. Validation of a new biomarker of fetal exposure to alcohol. J Pediatr (2003) 143:463-9. doi:10.1067/S00223476(03)00442-6

8. Bearer CF, Lee S, Salvator AE, Minnes S, Swick A, Yamashita T, et al. Ethyl linoleate in meconium: a biomarker for prenatal ethanol exposure. Alcohol Clin Exp Res (1999) 23:487-93. doi:10. 1097/00000374-199903000-00016
9. Bearer CF, Santiago LM, O’Riordan MA, Buck K, Lee SC, Singer LT. Fatty acid ethyl esters: quantitative biomarkers for maternal alcohol consumption. J Pediatr (2005) 146:824-30. doi:10.1016/j. jpeds.2005.01.048

10. Peterson J, Kirchner HL, Xue W, Minnes S, Singer LT, Bearer CF. Fatty acid ethyl esters in meconium are associated with poorer neurodevelopmental outcomes to two years of age. J Pediatr (2008) 152:788-92. doi:10.1016/j.jpeds.2007.11.009

11. Littner Y, Cudd TA, O’Riordan MA, Cwik A, Bearer CF. Elevated fatty acid ethyl esters in meconium of sheep fetuses exposed in utero to ethanol - a new animal model. Pediatr Res (2008) 63:164-8. doi:10.1203/PDR.0b013e31815f651e

12. Charness ME, Safran RM, Perides G. Ethanol inhibits neural cell-cell adhesion. J Biol Chem (1994) 269:9304-9.

13. Bearer CF, Swick AR, O'Riordan MA, Cheng G. Ethanol inhibits L1-mediated neurite outgrowth in postnatal rat cerebellar granule cells. J Biol Chem (1999) 274:13264-70. doi:10.1074/jbc.274. 19.13264

14. Tang N, Farah B, He M, Fox S, Malouf A, Littner $\mathrm{Y}$, et al. Ethanol causes the redistribution of L1 cell adhesion molecule in lipid rafts. J Neurochem (2011) 119:859-67. doi:10.1111/j.1471-4159.2011. 07467.x

15. Bearer CF, Linsalata N, Yomtovian R, Walsh M, Singer L. Blood transfusions: a hidden source of lead exposure. Lancet (2003) 362:332. doi:10.1016/ S0140-6736(03)13989-X

16. Bearer CF, O’Riordan MA, Powers R. Lead exposure from blood transfusion to premature infants. J Pediatr (2000) 137:549-54. doi:10.1067/mpd. 2000.108273

Conflict of Interest Statement: The author declares that the research was conducted in the absence of any commercial or financial relationships that could be construed as a potential conflict of interest.

Received: 18 February 2014; accepted: 08 March 2014; published online: 24 April 2014.

Citation: Bearer CF (2014) How Mary Ellen Avery influenced my career as an investigator. Front. Pediatr. 2:20. doi: 10.3389/fped.2014.00020

This article was submitted to Neonatology, a section of the journal Frontiers in Pediatrics.

Copyright (c) 2014 Bearer. This is an open-access article distributed under the terms of the Creative Commons Attribution License (CC BY). The use, distribution or reproduction in other forums is permitted, provided the original author(s) or licensor are credited and that the original publication in this journal is cited, in accordance with accepted academic practice. No use, distribution or reproduction is permitted which does not comply with these terms. 